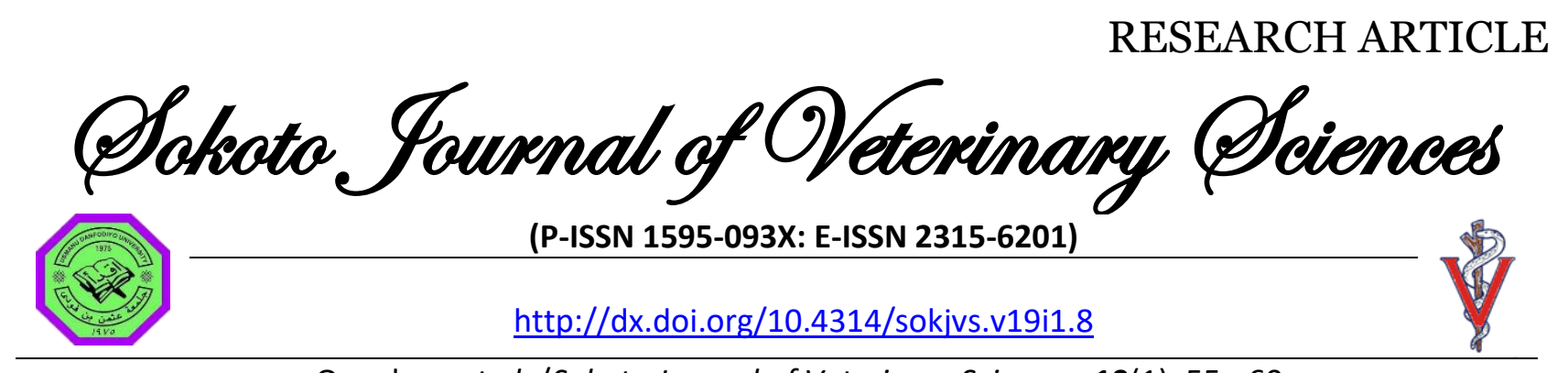

Ogunleye et al. /Sokoto Journal of Veterinary Sciences, 19(1): 55 - 60.

\title{
Total aerobic and Coliform counts from Oreochromis niloticus obtained from selected farms in Ibadan
}

\author{
SC Ogunleye*, OO Ishola, OM Faroyin \& OB Adedeji \\ Faculty of Veterinary Medicine University of Ibadan, Nigeria
}

*Correspondence: Tel.: +2348068029003; E-mail: ogunleyeseto@yahoo.com

\begin{abstract}
Copyright: (C) 2021
Ogunleye et al. This is an open-access article published under the terms of the Creative Commons Attribution License which permits unrestricted use, distribution, and reproduction in any medium, provided the original author and source are credited.
\end{abstract}

Publication History: Received: 04-09-2020

Revised: 27-01-2021

Accepted: 04-02-2021

\begin{abstract}
The environment where fishes are caught often determines their microbial flora, many of which are potential spoilers and not necessarily pathogenic to fishes but are implicated as cause(s) of serious foodborne illnesses and toxin-infections in humans, hence, their presence above permissible levels portends food-safety threats. This study showed the microbial load in Oreochromis niloticus obtained from selected farms in Ibadan, Nigeria. A total of 156 samples consisting of gills, intestines and skins were collected from 52 O. niloticus obtained from Egbeda-(A), Ido-(B), Ibadan-north east-(C) and Ibadan north-west-(D) Local Government Areas of Ibadan for Microbial Load \{Total Aerobic Count-(TAC) and Total Coliform Count-(TCC) $\}$ enumeration. TAC and TCC were performed using standard methods, and calculated in mean Log Colony Forming Unit \pm Standard Deviation ( $\log C F u \pm S D$ ). Data were analysed with ANOVA. Overall mean logCFu \pm SD TAC and TCC from gills, intestine and skin for the 156 samples were $8.65 \pm 0.28$ and $6.82 \pm 0.20$, respectively. Mean TAC $8.64 \pm 0.28,8.69 \pm$ 0.28 and $8.62 \pm 0.3$ and mean TCC $8.69 \pm 0.22,8.66 \pm 0.23$ and $8.73 \pm 0.22$ were obtained for gills, intestine and, skin respectively, with $p>0.05$. Means TAC $8.63 \pm$ $0.36,8.70 \pm 0.20,8.68 \pm 0.33$ and $8.56 \pm 0.14$ and TCC $8.56 \pm 0.25,8.86 \pm 0.16,8.65 \pm$ 0.18 and $8.69 \pm 0.16$ were observed for locations $A, B, C$, and $D$ respectively with $p<0.05$ for TAC and $p<0.05$. Mean microbial load counts obtained in this study was higher than permissible count of 7 logCFu/mL by International Commission on Microbiological Specification for Foods (ICMSF) for fresh fish, thus, portending public health threats.
\end{abstract}

Keywords: Oreochromis niloticus, Aerobic bacteria, Enterobacteriacea and Coliforms

\section{Introduction}

Aquaculture has become one of the fastest growing agricultural production industries worldwide in the recent times. This has been indicated in response to the global demands for proteins of animal sources, importantly, fish has competed favorably with meats from other animals (FAO, 2018). Several efforts towards ensuring sustainability of the human race through uplifting the agricultural industry has attracted massive supports from many global organizations, including, USAIDS and United Nations. Agricultural industry in many developing nations has become one of the sources of economic 
sustainability to farmers and national economy. Fish is widely accepted in most countries of the world because of its unique taste, flavor and good texture (Adebayo-Tayo et al., 2012). As part of human diet, it serves as a source of high digestible proteins, comprising many essential amino acids, vitamins, poly saturated fatty acids, omega-3, essential minerals as well as amounts of trace elements (Eman et al., 2018). Oreochromis niloticus, popularly known as tilapia is one of the most important and economic fish species globally (FAO, 2012), and in Nigeria, it has become one of the most popularly available and consumed fish species, like in many other nations (José et al., 2018). The successful production of fish in many developing Nations has unfortunately, been negatively impacted by the effects of infectious diseases and infectious agents. Many of these infectious diseases and infectious agents serve as food safety and public health threat to humans upon consumption and/or handling. Hence, aside from the enormous nutritional and health benefits of fishes, they serve as important contributor and sources of food borne illnesses and toxin-infections to humans (Norma et al., 2018) through the consumption of contaminated fish and fish products. Although, the microbial flora of fish is principally the function of the environment from which they are raised and not necessarily of the fish species, the microorganisms culturable from fish can vary significantly (Ibrahim et al., 2014). Because of their soft tissues, high digestible protein, high water content and other essential minerals and nutrients, coupled with the aquatic environment, fish are extremely susceptible to microbial contamination (Ibrahim et al., 2014). Fish parasites may be broadly grouped as bacteria, fungi, virus, and protozoan etc. Many of the microorganisms associated with fish are not pathogenic to fish (Adedeji et al., 2011; Elhadi et al., 2016). Bacteria, many of which are potential spoilers are present in the surface slime, gills and intestines of live fish, although the flesh itself is normally sterile. These associated bacteria include; Streptococcus spp., Staphylococcus spp., Salmonella spp., Shigella spp., Pseudomonas spp., Escherichia coli (E. coli), Klebsiella spp., Enterobacter spp., Enterococcus spp., Campylobacter spp., and Proteus spp. (Adedeji et al., 2011; Elhadi et al., 2016). The growth conglomerate of the diverse microorganisms culturable on conventional agar plates is known as total microbial load. The Aerobic Plate Count (APC) is used as an indicator of bacterial populations on a sample. It is also called the aerobic colony count, standard plate count, Mesophilic count or Total Plate Count, while the enumeration of the enteric bacteria is known as Total Coliform Count (TCC). The presence of the aerobic bacteria and enterobacteria group from food samples indicates human possible health risks from the consumption of those samples. The mean $\log \mathrm{CFu} / \mathrm{g}$ microbial count for fresh fish ranges between logCFu5-7 (NAFDAC,2019; ICMSF, 2005). A mean above logCFu 7 is unacceptable for fresh fish as it could serve as a source of infection to human.

In response to several bacterial infections and foodborne illnesses, many antibiotics have been devised to combat the impacts of these organisms both in fish production and in humans. However, incessant and indiscriminate use of antibiotics as well as abuse of available antimicrobials has jointly contributed to the global menace of antimicrobial resistance (AMR). Antimicrobial resistance (AMR) has now been known to be of global public health concern. It is estimated that by 2050 , drug resistant infections are likely to cause death of 10 million people annually, if the current trends of antimicrobial resistance persist (Crump et al., 2011; Dadgostar, 2019).

This study was aimed at accessing the microbial load from $O$. niloticus sold in Ibadan, Oyo State. Outcomes from this study would be vital tools for addressing food safety and public health issues.

\section{Materials and Methods}

\section{Sampling method and sample collection}

A cross-sectional study involving fish farms raising Tilapia in four Local Government Area (LGA) of Ibadan, Oyo State was conducted. The LGAs were purposefully sampled based on the availability of fish farms cultivating Oreochromis niloticus. They include, Egbeda (A), Ibadan north west (B), Ido (C), and Ibadan north east (D) LGAs. Four farms comprising two feral (1 and 2) from A and B LGAs and two cultured farms ( 3 and 4 ) from $C$ and D LGAs were purposively selected for sample collection. A total of fifty-two (52) apparently healthy, table-sized (average weight $120 \mathrm{gm}$ ) live tilapia comprising 16 each from the feral farms ( 1 and 2 ) and 10 each from cultured farms ( 3 and 4 ) were collected between July and August 2019. Sampled tilapia fish were transported to the Food and Milk Hygiene Laboratory of the Department of Veterinary Public Health and Preventive Medicine, University of Ibadan for bacteriological analysis.

On arrival at the laboratory, fish were stored briefly in the transport medium containing sterile water, and were properly identified and organs of interest were aseptically harvested using scalpel. One gram (1gm) each of samples of gills, intestine and skin 
were collected and aseptically macerated separately with buffered peptone water (LabM ${ }^{\circledR}$, UK). A total of 156 samples consisting of gills $(n=52)$, intestines $(n=52)$ and skins $(n=52)$ were therefore obtained from the 52 Oreochromis niloticus for bacteriological analysis. Samples were processed according to the protocols recommended by microbiological Standards and Guidelines by International Organization for Standardization (ISO 6887-16579, 2017).

Microbial load (total aerobic count and total Coliform count)

Total Microbial load was carried out according to the International Organization for Standardization ((ISO 6887-16579, 2017).). Non-selective pre-enrichment was performed by aseptically harvesting $1 \mathrm{gm}$ of tissue sample, and then homogenised in $9 \mathrm{mls}$ buffered peptone water $\left(\right.$ LabM $^{\circledR}$, UK) in a test-tube to give a dilution of 1:10. Test-tubes were corked properly, labeled and incubated overnight at $37^{\circ} \mathrm{C}$.

Serial dilution of sample and microbial load enumeration

A 10-fold serial dilution of each of the samples in a series of dilution tubes was prepared. At first for each of the processed samples 6 sterile test tubes were placed on a test tube holder rack containing 9 $\mathrm{ml}$ of $10 \%$ buffered peptone water (LabM ${ }^{\circledR}$, UK). One millilitre $(1 \mathrm{~mL})$ of pre-enriched sample was mixed with $9 \mathrm{ml}$ of buffered peptone water (BPW) in a test tube to make $10-1$ dilution. Then $1 \mathrm{ml}$ of the solution from the 1st test tube is mixed with $9 \mathrm{ml} \mathrm{BPW}$ in a 2nd test tube. The serial dilution continues until the 6th test tube. Inocula (each $0.1 \mathrm{ml}$ ) taken from the third and fifth test tubes with Dilution Factors (DF) 10-4 and 10-6 5 respectively were spread onto Nutrient $\left(\right.$ LabM $^{\circledR}$, UK) and MacConkey agar $\left(\right.$ LabM $^{\circledR}$, UK) plates. The plates were incubated at $37^{\circ} \mathrm{C}$ for 24 hours. The bacterial colonies were counted using a Colony Counter and the Mean and Standard Deviations were calculated. Mean was converted to
CFU by multiplying the number of colonies by the dilution factor and the product divided by the volume plated, and CFU was interpreted to log10CFU by multiplying the CFU by $\log 10$ (log10CFU $\pm S D)$.

\section{Data analysis}

Data was analyzed using descriptive statistics and difference of means was determined using Analysis of Variance (ANOVA).

\section{Ethical approval}

The study was approved by the Animal Care and Use Research Ethics (ACUREC), University of Ibadan, Nigeria, with approval number: UI-ACUREC/19/0079. Samples were collected from consenting farmers raising tilapia fish.

\section{Results}

Total aerobic counts (TAC) and total Coliform count (TCC) of bacteria from tilapia

The overall mean logCFu \pm SD of the Total Aerobic Count (TAC) and Total Coliform Count (TCC) from the 156 samples showed $8.65 \pm 0.28$ (TAC) and $6.82 \pm$ 0.20 (TCC). Mean TAC $8.64 \pm 0.28,8.69 \pm 0.28$ and $8.62 \pm 0.3$ and mean TCC $8.69 \pm 0.22,8.66 \pm 0.23$ and $8.73 \pm 0.22$ (Table 1) were obtained for gills, intestine and, skin respectively, with $p>0.05$. Means TAC 8.63 $\pm 0.36,8.70 \pm 0.20,8.68 \pm 0.33$ and 8.56 \pm 0.14 and TCC $8.56 \pm 0.25,8.86 \pm 0.16,8.65 \pm$ 0.18 and $8.69 \pm 0.16$ were observed for locations $A$, $B, C$, and $D$ respectively with $p<0.05$ for TAC and $\mathrm{p}<0.05$ (Table 2).

Highest Mean TAC was observed for the intestine while for the TCC, was found in the skin while location $B$ has the highest mean for both mean TAC and TCC.

No significant difference was observed between the means of TAC for all the locations $(p<0.05)$ A significant difference was observed between means TC from all the 4 Locations $(p<0.05)$ (Table 2).

Table 1: Overall Mean Total Aerobic Counts (TAC) and Total Coliform Count of bacteria organs and fishes of tilapia fish sampled in LogCFu/g

\begin{tabular}{|c|c|c|c|c|c|c|}
\hline \multirow[t]{2}{*}{ Fish organs } & \multicolumn{3}{|c|}{ TAC } & \multicolumn{3}{|c|}{ TCC } \\
\hline & $\begin{array}{l}\text { Mean } \pm \text { SD } \\
(\log C F u / g)\end{array}$ & Range & P-Value & $\begin{array}{l}\text { Mean } \pm \text { SD } \\
(\log C F u / g)\end{array}$ & $\begin{array}{l}\text { Range } \\
\text { (logCFu/g) }\end{array}$ & P-Value \\
\hline Gills & $8.64 \pm 0.28$ & $8.21-9.16$ & $P=0.336213$ & $8.69 \pm 0.22$ & $6.48-7.24$ & $P=0.15052$ \\
\hline Intestines & $8.69 \pm 0.28$ & $7.96-9.01$ & $(p>0.05)$ & $8.66 \pm 0.23$ & $6.35-7.16$ & $(p>0.05)$ \\
\hline Skin & $8.62 \pm 0.3$ & $7.91-9.12$ & & $8.73 \pm 0.22$ & $6.10-7.23$ & \\
\hline Overall mean & $8.65 \pm 0.28$ & & & $8.7 \pm 0.22$ & & \\
\hline
\end{tabular}


Table 2: Comparison of Total Aerobic Counts (TAC) and Total Coliform Count of bacteria in logCFu/g of tilapia fish sampled from 4 LGA; (Egbeda $\{A\}$, Ibadan north west $\{B\}$, Ido $\{C\}$, and Ibadan north east $\{D\}$ Local Government Areas $\{L G A\})$

\begin{tabular}{lllllll}
\hline Locations & \multicolumn{3}{c}{ TAC } & & \multicolumn{2}{c}{ TCC } \\
\cline { 2 - 7 } & $\begin{array}{l}\text { Mean } \pm \text { SD } \\
(\operatorname{logCFu} / \mathrm{g})\end{array}$ & $\begin{array}{l}\text { Range } \\
(\log C F u / g)\end{array}$ & P-Value & $\begin{array}{l}\text { Mean } \pm \text { SD } \\
\text { (logCFu/g) }\end{array}$ & $\begin{array}{l}\text { Range } \\
\text { (logCFu/g) }\end{array}$ & P-Value \\
\hline $\mathrm{A}$ & $8.63 \pm 0.36$ & $7.84-9.21$ & $\mathrm{P}=0.151308$ & $8.56 \pm 0.25$ & $7.91-9.07$ & $\mathrm{P}=2.92 \mathrm{E}-11$ \\
$\mathrm{~B}$ & $8.70 \pm 0.20$ & $8.32-9.02$ & $(\mathrm{p}>0.05)$ & $8.86 \pm 0.16$ & $8.61-9.16$ & $(\mathrm{p}<0.05)$ \\
$\mathrm{C}$ & $8.68 \pm 0.33$ & $8.22-9.25$ & & $8.65 \pm 0.18$ & $8.40-8.90$ & \\
\hline $\mathrm{D}$ & $8.56 \pm 0.14$ & $8.33-8.90$ & & $8.69 \pm 0.16$ & $8.50-9.01$ & \\
\hline
\end{tabular}

\section{Discussion}

The findings of the Total Aerobic Count (TAC) and Total Coliform Count (TCC) from different organs of O. niloticus (tilapia) sampled in this study are indicative of the presence of bacteria and especially, Enterobacteriacea from tilapia in Ibadan. The Coliform count at levels $>10^{5} \mathrm{CFU} / \mathrm{ml}$ intrigues public health and food safety concern about the hygienic status of the production and point of sale environment. The observed higher TAC than TCC is expected as the TAC implies all the aerobic bacterial present in the fish sampled while TCC implies all the Coliforms (Enterobacteriacea) present. The nonsignificant difference $(p>0.05)$ observed between the mean counts among the tested organs conforms with the report of Adedeji et al. (2011) and contrasts report of Ibemenuga et al. (2014). This observation is similar to the report from the study of Shinkafi et al. (2010). This finding of aerobic bacteria and Enterobacteria group in this study indicates possible health risks of consuming fish collected from ponds and rivers from these areas.

The overall mean logCFug- 1 obtained in this study is higher than the maximum recommended public health and safety standard value of: $5.0 \times 10^{5} \mathrm{CFU}$ g1 , as approved by Food and Agricultural Organisation (FAO, 1979), Nigerian National Agency for Drug Administration and Control \{NAFDAC\} (Ezeri et al., 200

1) and International Commission on Microbiological Specification for Foods \{ICMSF, 1986\} Sohana \& Ekramul (2016). Hence, fishes from the sampled locations could pose potential threat of foodborne illnesses to consumers and/or handlers. The overall mean TAC count recorded in this study is however lower as compared to the findings of Adedeji et al. (2012) and higher in contrast to the study by Hillary et al. (2018) where a mean of logCFu/g of 4.4 was reported.

The observed mean counts obtained in this study could be due to human activities and contamination of water bodies observed at sampling locations; these observations were similar to the reports of
Adedeji et al. (2011), while the statistical differences observed between locations $A$ and $B$ could be due to factors listed above as well as restriction of human activities observed at location A during sample collection. The statistical difference observed between mean TCC of location C and D could be due to pollution, improper drainage systems and run-off of water into farm $C$ observed during sample collection. Ponds and rivers that harbour fish could serve as an important source of contaminants to fish due to indiscriminate deposition of human and animal excreta and other environmental wastes into water bodies. Free roaming animals including: birds and pets especially, dogs contribute to faecal contamination of surface waters (Doyle et al., 1997). Outcomes from this study established a poor microbial quality as the mean TAC and TCC were both found higher than the minimum acceptable microbial counts on tilapia of fish obtained from both feral and cultured farmed $O$. niloticus in Ibadan, southwest Nigeria; this agrees with the report of Adedeji et al. (2012).

This study confirms the extent of microbial contamination of tilapia sold in Ibadan, and affirms that the fish sold are laden with microbial load higher than recommended count on fresh fish. Based on the aforementioned observations in this study, it is recommended that further studies geared towards understanding and characterizing microorganisms, especially, the zoonotic types should be prioritized. This further study would be important for understanding the pathogenesis of the different diseases that might be caused by these organisms and further might help in designing protective measures. Furthermore, because Coliforms were found at above permissible levels, hence, awareness should be created among fish farmers and stakeholders on possible health hazards accompanying handling and/or consumption of fresh and undercooked fish. Conclusively, regulatory policies and standard operating practices for hygienic practices in the fishing and aquatic environments, controlled human activities, fishing 
procedures and handling of fish should be instituted and be followed by fishers and farmers to avoid disease outbreaks.

\section{Acknowledgment}

We wish to appreciate all the participants involved in this study, Olayemi Okunlade, Dr G. O Oladosu and Fish farmers, and the department of Department of Veterinary Public Health and Preventive Medicine University of Ibadan, Nigeria.

\section{Conflicts of Interest}

The authors declare no conflict of interest.

\section{References}

Adebayo-Tayo BC, Odu NN, Anyamele LM, Igwiloh NJPN, \& Okonko IO (2012). Microbial

Quality of Frozen Fish Sold In Uyo Metropolis. Nature and Science, 10(3): 71-77.

Adedeji OB, Okerentugba PO, Innocent DE, Adiele HC, \& Okonko IO (2012). Benefits, public health hazards and risks associated with fish consumption. New York Science Journal, 5(9): 33-61.

Adedeji OB, Tiamiyu AM, \& Emikpe BO (2011). The antibiotic resistant patterns of bacterial flora of fish from different aquatic environments from Ibadan, south-west Nigeria. Journal of Advanced Environmental Biology, 5(8): 2039-2047

Crump JA, Medalla FM, Joyce KW, Krueger AL, Hoekstra RM, Whichard JM \& Barzilay EJ (2011). Antimicrobial resistance among invasive nontyphoidal Salmonella enterica isolates in the United States: national antimicrobial resistance monitoring system, 1996 to 2007. Journal of Antimicrobial Agents Chemotherapy, 55(3):1148-54.

Dadgostar P (2019). Antimicrobial Resistance: Implications and Costs. Infection and Drug Resistance, doi.10.2147/idr.s234610.

Doyle JJ, Ballenger JA, Dickson EE, Kajita T \& Ohashi $H$ (1997). A phylogeny of the chloroplast gene rbclin the Leguminosae: taxonomic correlations and insights into the evolution of nodulation. American Journal of Botany, doi.10.2307/2446030.

Elhadi N, Aljeldah M \& Aljindan R (2016). Microbiological contamination of imported frozen fish marketed in eastern Province of Saudi Arabia. International Food Research Journal, 23(6): 2723-2731.
Eman N, Amr F, Fatma AA, \& Madiha SI (2018). Isolation, Identification and Pathogenicity Characterization of Edwardsiella tarda Isolated from Oreochromis niloticus Fish Farms in Kafr-Elshiekh, Egypt. Alexander Journal of Veterinary Science, 57(1): 171179.

Ezeri GNO (2001). Haematological response of Clarias gariepinus to bacterial infection and prophylactic treatment with antibiotics. Journal of Aquatic Science, doi.10.4314/jas.v16i1.19996

FAO (1979). CFU g-1, as approved by Food and Agricultural Organization (FAO, 1979). Retrieved from: http://www.fao.org/3/T0610E/T0610E.pdf. Accessed on: 04/04/2020

FAO (2012). Food \& Agriculture Organization. The State of World Fisheries and Aquaculture 2012: Contributing to Food Security and Nutrition for All. Food and Agriculture Organization, Rome Italy. FAO Fisheries Technical Paper, pp 200.

FAO (2018). Food \& Agriculture Organization. The production of fish meal and oil. Fisheries Industries Division, Food and Agriculture Organization of the United Nations, Rome, Italy. FAO Fisheries Technical Papers, Pp142.

Hillary AO, Musa ON, Mercy M, Joseph W \& Patrick MK N (2018). Microbiological Safety of Fresh Tilapia (Oreochromis niloticus) from Kenyan Fresh Water Fish Value Chains. Journal of Food Protection, 81(12): 1973-1981.

Ibemenuga KN \& Okeke TE (2014). Bacteriological quality of freshwater fish caught from two natural lakes in the rainforest region of south-eastern Nigeria. Journal of Animal Research International, 11(2): 1946 - 1952

Ibrahim AR, Lawan FA, Bello HS, Musa AS, Ameh JA \& Ambali AG (2014). Occurrence and antimicrobial susceptibility profiles of Salmonella serovars from fish in Maiduguri, sub-Saharah, Nigeria. Egyptian Journal of Aquatic Research doi.10.1016/j.ejar.2014.01.003

ICMSF (1986). Microorganisms in Foods, Sampling for Microbiological Analysis: Principles and Specific Applications. Second edition, University of Toronto Press, Toronto.

ICMSF (2005). Microorganisms in Foods, Sampling for Microbiological Analysis: Principles and 
Specific Applications. Second edition, University of Toronto Press, Toronto.

ISO 6887-1 (2017). Microbiology of the food chain Preparation of test samples, initial suspension and decimal dilutions for microbiological examination - Part 1: General rules for the preparation of the initial suspension and decimal dilutions

José AV, Sylvia P D, Julio AC, Magdalena de JU, María del CC, Ignacio O \& María, EB (2018). Microbiological Analysis Of Tilapia And Water In Aquaculture Farms From Sinaloa; Biotecnia, XX(1): 20-26.

NAFDAC (2019). National Agency for Food \& Drug Administration \& Control. Guidelines and standards for foods and water. National Agency for Food \& Drug Administration \&
Control,

Nigeria. https://www.nafdac.gov.ng/wp- CFU g-1, retrieved 40-04-2020

Norma H \&Santos G (2018). Animals as sources of food-borne pathogens: A review. Animal Nutrition, 4(3) on 14 October.

Shinkafi SA \& Ukwaja VC (2010). Bacteria Associated with Fresh Tilapia Fish (Oreochromis niloticus). Sold at Sokoto Central Market in Sokoto, Nigeria. Nigerian Journal of Basic and Applied Science, 18(2): 217-221.

Sohana AIS \& Ekramul KMd (2016). "Microbiological Quality Assessment of Frozen Fish and Fish Processing Materials from Bangladesh." International Journal of Food Science, vol., Article ID 8605689. 